\title{
Crop Theft and Soil Fertility Management in the Highlands of Ethiopia
}

\author{
Linley Chiwona-Karltun ${ }^{1}$ \\ Mulugeta Lemenih ${ }^{2}$ \\ Motuma Tolera ${ }^{2}$ \\ Tadesse Berisso ${ }^{3}$ \\ and Erik Karltun ${ }^{4}$ \\ ${ }^{1}$ Department of Urban and Rural Development, Swedish University of Agricultural Sciences \\ (SLU), Box 7012, 75007 Uppsala, Sweden \\ ${ }^{2}$ Wondo Genet College of Forestry, Hawassa University, Ethiopia \\ ${ }^{3}$ Institute of Ethiopian Studies, Addis Abeba University, Ethiopia \\ ${ }^{4}$ Department of Soils and Environment, Swedish University of Agricultural Sciences (SLU) \\ Contact author: Linley Chiwona-Karltun: linley.karltun@sol.slu.se
}

\begin{abstract}
Theft of crops in rural areas is largely attributed to poverty and hunger. Crop theft has the consequence of soil fertility management being vastly impaired, a possible association examined by very few studies. The emphasis of most soil fertility studies has been on the effect of biophysical conditions and economics, which are the lack of capability of farmers as well as the failure of macro-economic policies to support good soil fertility management practices. The challenges that farmers face at the individual, household and community levels, as well as the barriers hampering farmers from practicing adequate soil fertility management, are still poorly understood. We need to extend our thinking beyond contextual issues of poverty, hunger, climate and seasonality to acquire a more nuanced understanding of food security in transforming rural agrarian societies. This study investigated the role of crop theft, particularly of legume bean crops, and its impact on soil fertility management. The results revealed that crop theft of legume bean crops deteriorated local intercropping and crop rotation soil fertility management practices. Crop theft had serious consequences on other socio-economic and cultural aspects of day-to-day life that deteriorated human relationships and eroded trust.
\end{abstract}

Keywords: beans, crop rotation, Ethiopia, food security, soil fertility, theft, trust, women

(c) (i) $\Theta ~(C) 2017$ Chiwona-Karltun, Lemenih, Tolera, Berisso, \& Karltun. This article is published under a Creative Common AttributionNoDerivatives 4.0 International License (https://creativecommons.org/licenses/by-nd/4.0/) 


\section{Introduction}

Reduced soil fertility is prominent in Sub-Saharan Africa (SSA). The underlying reasons for this range from historical legacies, poor policies of the political systems, and climate change to resource conflicts and low human capital (Sachs and Warner 2001; Collier 2007). Being a major biophysical core of the declining food production in SSA, reduced soil fertility results in escalated food insecurity as well as intensified conflicts (Lemenih, Karltun and Olsson 2005).

\section{Crop theft and its consequences}

When confronted with environmental issues, such as seasonality and climate, any crisis experienced by farmers in this region is amplified due to a weak socioeconomic system (Clay, 1981). How soil fertility in SSA relates to biophysical conditions, economic inadequacy or macro-political policies has been extensively studied, however, the daily challenges at the household and community level, hampering farmers from practicing adequate soil fertility management, have not as yet been clarified.

During periods of food shortages, caused by various kinds of disasters, theft of crops and livestock is common, probably as a means of coping with these crises (Chiwona-Karltun et al. 1998; Mkumbira et al. 2003; Chiwona-Karltun et al. 2005), and studies by Faf Champs (2006) confirmed that "crop theft is systematically related to increases in transitory poverty and these findings survive even after controlling for changes in law enforcement". His study furthermore disclosed that crop theft was strongly related to the degree of enforced isolation, due to unaffordable transport costs.

No study has reported on how soil fertility management is affected by systematic crop theft, and inspired by Faf Champs' studies in Madagascar, the present study thus investigated the impact of bean theft on this issue. Soil fertility is intertwined with productivity, thus directly affecting food security and the subsequent level of poverty in a farm community. The study describes how serious social problems (gender and human relations, indigenous institutions), caused by systematic theft of legume crops (particularly beans), affected soil nutrient management practices and cropping patterns, which in turn altered food availability and habits, and ultimately the livelihoods of farmers in southern Ethiopia. 


\section{Materials and Methods}

\section{Study area}

The chosen study area, the village Beseku, was located approximately at $7^{\circ} 20^{\prime} \mathrm{N}$ and $38^{\circ} 45^{\prime}$ E, about 240 kilometres (about 150 miles) south of the capital city, Addis Ababa. The farm fields of the village lie on a flat topography, near the bottom of the eastern escarpment of the Rift Valley, at an altitude of about 2100 metres above sea level (about 6,900 feet). The rainfall has a bimodal distribution, the short rainy season extending between March and June and the major rainy season between July and October. According to the meteorological records at Degaga (2000 meters or 6,500 feet above sea level), 9 kilometres (5.6 miles) from the study area, the mean annual precipitation is $1.075 \mathrm{~mm}$ and the mean annual temperature is about $15^{\circ} \mathrm{C}$ $\left(60^{\circ} \mathrm{F}\right)$. The soils of the area are developed in volcanic ash deposits from quaternary (i.e., over approximately the past 2.6 million years) volcanic activities in the Rift Valley and its surroundings, and they are classified as Mollic Andosols (ISSS-ISRIC-FAO, 1998) or Humic Haplustands (Lemenih 2004). The soil fertility of the area should thus be of top quality, but in fact, crop yields have decreased, possibly due to diminished soil fertility. This is one reason why the area around Besoko was selected for this study.

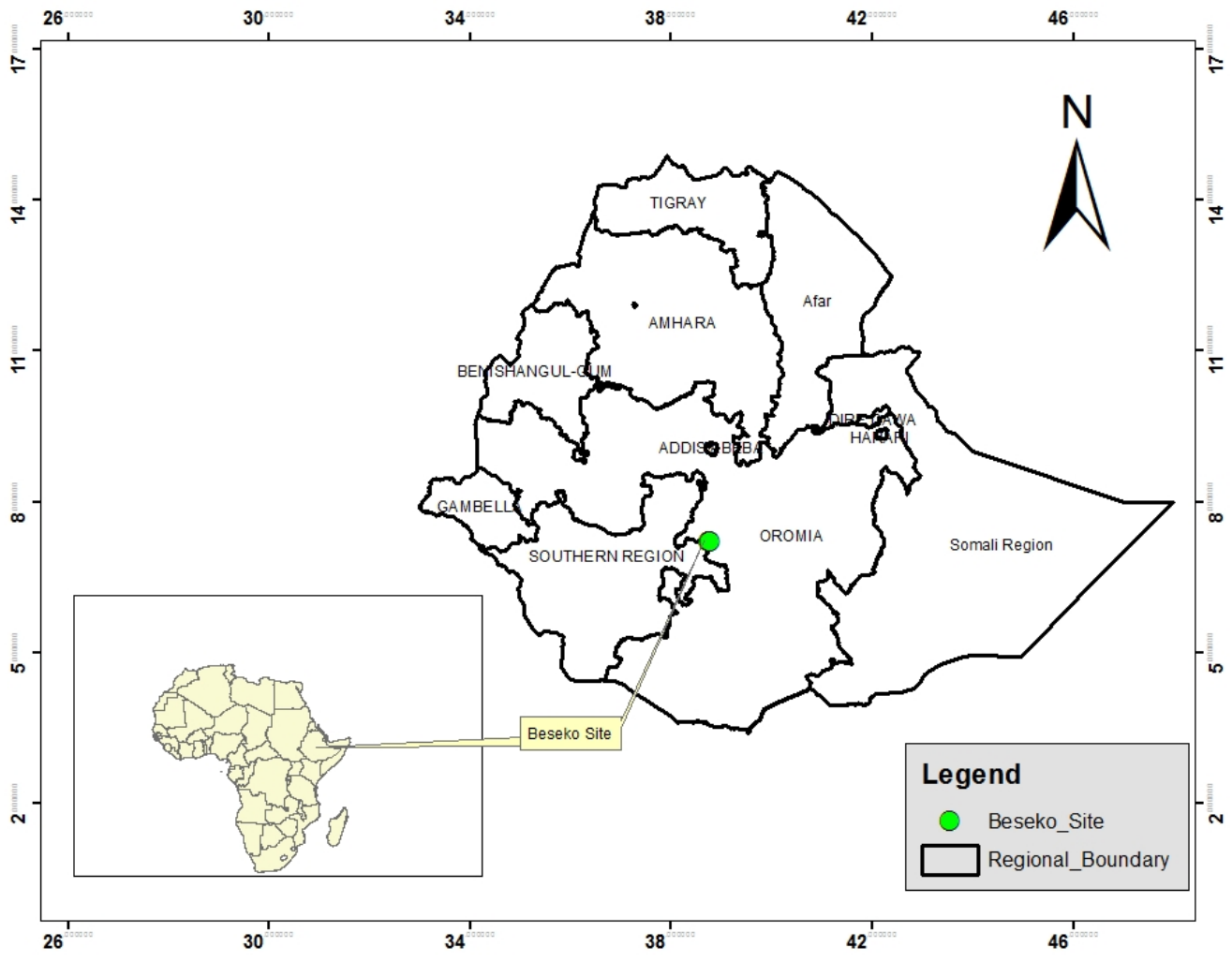

Figure 1: Location of the Study Site 
Crop Theft and Soil Fertility Management in the Highlands of Ethiopia - Chiwona-Karltun, Lemenih,

Tolera, Berissso, and Karltun

\section{Ethnic groups in Beseko}

Beseku comprises a mix of Arsi Oromo, Shewa Oromo and Kambata ethnic groups. Settlement farming in Beseko has a relative short history compared to the central or northern plateaus of Ethiopia. Consequently, farmers in Beseku do not have a long, extensive farming experience. The natives of the area, the Arsi Oromo, were pure pastoralists just 30-35 years ago, and thus the tradition of crop cultivation draws upon the experience of only two to three generations. Farming was established in the area along with the progressive migration of the northern Shewa Oromo people to the area, contributing to population growth.

\section{Farming system}

The predominant farming system in Beseko is a mixed crop-livestock production system. Important crops included maize, wheat, sorghum, barley and potato, maize being the main staple crop. The policies and infrastructure for producing maize have become more and more favourable, but at the expense of other crops, such as sorghum and barley. Important livestock were cattle, horse, and donkey; all three were used as draught power as well as for transport, while sheep and goats were kept primarily for income generation. Tables 1 and 2 display information for the type of crop grown by the wealth group and the age of farmers, respectively.

Table 1: General information about annual crops grown by the interviewed households according to wealth groups

\begin{tabular}{llllllll}
\hline \multirow{2}{*}{$\begin{array}{l}\text { Wealth } \\
\text { group }\end{array}$} & \multirow{2}{*}{$\begin{array}{c}\text { Number of } \\
\text { households }\end{array}$} & \multicolumn{5}{c}{ \% of households growing a certain crop } \\
\cline { 3 - 8 } & & Maize & Sorghum & Wheat & Barley & Teff & Bean \\
\hline Poor & 36 & 94 & 39 & 72 & 42 & 11 & 3 \\
Average & 35 & 89 & 54 & 83 & 46 & 17 & 6 \\
Rich & 29 & 86 & 59 & 86 & 69 & 34 & 3 \\
\hline
\end{tabular}

Table 2: Annual crops grown by the interviewed households according to age groups over the last couple of years

\begin{tabular}{llllllll}
\hline Age groups & \multirow{2}{*}{$\begin{array}{c}\text { Number of } \\
\text { households }\end{array}$} & \multicolumn{5}{c}{ \% of households growing a certain crop } \\
\cline { 3 - 8 } & 6 & 83 & 67 & 83 & 33 & 0 & 0 \\
\hline$<21$ & 6 & 81 & 69 & 75 & 38 & 25 & 0 \\
$21-40$ & 34 & 91 & 29 & 79 & 44 & 15 & 3 \\
$41-60$ & 44 & 93 & 56 & 81 & 63 & 23 & 7 \\
$>60$ & 16 & & & & &
\end{tabular}




\section{Data collection}

Data were collected in terms of a series of interviews, starting with a randomized household semi-structured questionnaire survey in 2006, followed by key informant in-depth interviews, and focus group discussions between February 2007 and June 2008.

The data obtained from the questionnaire survey were fed into a database and analyzed descriptively, whereas qualitative data collected from the interviews and focus group discussions were transcribed in Oromiffa and translated into English. For each interview, there was an interpreter, a note taker and a moderator conducting the interview, to ensure a smooth flow of the conversation. Each interview and discussion was tape-recorded digitally upon the consent of the interviewees, and transcribed manually into running text.

\section{Initial survey}

The focus of the initial questionnaire survey was to collect information on soil fertility status, perceptions, knowledge and impediments to sustainable agricultural production in the area by means of individual interviews using structured questionnaires. For this, 100 households were randomly selected as follows: a list of all household heads (male and female) living in the study area was acquired from the Peasant Association (PA) office, and with the help of key informants (village elders and PA leaders), the households were grouped into three wealth categories: poor, medium and rich, from which 36,35 and 29 households respectively were randomly selected, resulting in wide age classes (Table 1). The questionnaire was translated from its original English language to the local language (Oromiffa). To check the quality of the translation and to be able to resolve any linguistic and interpretational ambiguities, the questionnaire was retranslated into English using an independent translator, and final corrections were made in the Oromiffa version. Ten trained (by authors) enumerators from the village performed the interviews in pairs (one male, one female).

\section{In-depth interviews}

The interviews with key-informants illuminated the necessity of a deeper examination of certain topics. Thus, a checklist of further questions was prepared for in-depth interviews with five key informants. Analyzing the results of the two series of interviews identified topics for the focus group discussions. 


\section{Crop Theft and Soil Fertility Management in the Highlands of Ethiopia - Chiwona-Karltun, Lemenih,}

Tolera, Berissso, and Karltun

\section{Focus group discussions}

Seven focus group discussions were carried out, six of which in single gender groups (three groups of each gender), comprising 8-12 persons. The last discussion entailed 20 participants of both genders. Participants were selected on the basis of three distinct groups of ethnicity and religion being represented in the area.

\section{Results}

The survey and the interviews revealed three important and negative developments in the area: altered cropping patterns, diminished land availability, and increasing insecurity associated with crop theft. Farmers pointed to external factors as the main reasons for these developments and suggested changing socioeconomic conditions, agro-ecological shifts and the geopolitical arena as the underlying causes.

\section{Consequences of altered cropping patterns}

Farmers in the study area have abandoned growing the traditional cereals barley and sorghum in favour of wheat and maize, and to some extent Irish potatoes. The biggest change is the magnitude of the crop replacement. Farmers expressed being coerced into this shift by means of changed availability of inputs, e.g. high yielding seeds for maize, timely accessibility of fertilizer as well as ease of marketing, and final yield. Consequently, maize production now substantially dominates over barley.

Another modification in crop choice concerns beans, common in the study area less than a decade ago. Increasing occurrence of theft has resulted in diminished cultivation of this legume. Consequently, in spite of the supreme soil improving features of beans, few farmers incorporated them in the crop rotation system (Table 3), but rather rotate maize, wheat and sorghum. The farmers communicated, however, that they recognized and had experienced beans as an important crop; they had previously been included in the crop rotation system. Any crop grown after beans had given a good yield. The farmers of the present study expressed severe distress for their future agricultural productivity, ascribing it to increasing prices of fertilizer and the concurrent absence of nitrogen fixating legumes, i.e. beans, as well as the changing climatic conditions. 


\section{Land availability}

Around Beseko, the forestland has been converted to farmland as a necessary response to an increasing population. This has left little or no common land available for herding livestock, a drastic change to the people of Beseko, who traditionally used to be pastoralists. Women and children now have to keep livestock at home, which in a way has some benefits, like donkeys being available for transporting water and providing manure for the home gardens. The intense farming, along with unpredictable rainfalls and scarcity of water, has however brought new challenges. Adequate management to avoid soil fertility deprivation should be prioritized in order to maintain a sustainable livelihood as a farmer. This is, however, hindered by socioeconomic factors, e.g. seed and fertilizer not being available or delivered until after the planting season, and the soaring prices of fertilizer add an extra dimension to the problems. Farmers commented that had it not been for the socioeconomic factors and the theft of legumes, soil fertility decline would have been a minor problem.

\section{Implications of crop theft on the community}

The farmers considered the Beseko community a very suitable area for crop production. They described it as "a site where you could grow anything but salt". In all interviews, however, the farmers repeatedly expressed the escalation of theft as an overwhelming challenge for agricultural productions systems, crops and livestock, and during one of the focus group discussions the words thief, theft, steal and stolen were mentioned 58 times by the discussants. They felt that thievery was correlated to declining landholdings, poverty and unemployment among young people, but they also included changing times with prolonged hunger periods, food shortage, and the exorbitant cost of beans as a sizable part of the problem.

Two reasons were given for why stealing beans and peas had become such a serious problem: First, by-passers always used to sample beans while in the field, just for a taste. However, this sampling had now increased to such a magnitude that it no longer could be regarded as tasting, but had to be classified as theft. Farmers now used a proverb when describing this practice: "Bean fields and pretty girls cannot be passed by without picking and tasting”. Second, many by passers picking or stealing beans from small-scale productions on small family plots, leaves little for the family to harvest at the end. Consequently, households would be short of beans for making the sauce for the staple dish injera.

The farmers in Beseko therefore stopped growing beans to avoid conflict in the community. Previous efforts to stop offenders (thieves) had often resulted in community scale conflicts due to strong kinship bonds among the different groups or clans living in the area. 
Crop Theft and Soil Fertility Management in the Highlands of Ethiopia - Chiwona-Karltun, Lemenih,

Tolera, Berissso, and Karltun

\section{Forced dietary changes and health}

The sauce that accompanies the traditional staple food, injera, is made from beans. Men as well as women in Beseko reported on their dietary habits having changed due to the absence of beans in their farming system. "The main dietary-related problem facing us is not what to eat in terms of bread or cereal but what to eat with it - the sauce”. The farmers further added:

"Nowadays it is expensive to buy peas and beans from the market for making the sauce, and at times we are forced to just eat the injera bread without sauce. This is made worse by the fact that the injera is no longer made from teff but from maize”. During normal times, the price of beans at the market was $18 \mathrm{Birr} / \mathrm{kg}$ ( $1 \mathrm{USD}=7 \mathrm{Birr})$, but this price was increasing now that farmers excluded beans from their farming. The farmers also revealed that bad health among family members and frequent visits to the clinic, particularly by young children and the elderly, were more common, and they attributed this transformation to dietary modifications, changing times and socio-economic factors.

\section{Downward spiral of "household economics"}

Apart from being an important food crop, beans fetched higher prices than any other crop grown in the area. Farmers declared that, depending on the season, $100 \mathrm{~kg}$ of beans may be sold on the market for 400-600 Birr (2008), a 3-4 times higher price than for the same amount of maize (100-180 Birr/100 kg). The farmers expressed a great disappointment over the economic loss their households suffered since they stopped growing beans. In the end, households ceased to grow beans to avoid conflicts due to the extensive thieving of crops, forcing households to buy beans from the market. To raise money for this, they had to sell other crops, but for a lower price. Consequently, the meagre financial resources of the households are put under extreme pressure. As one of the farmers explained:

"We have to sell a sack full of maize to be able to buy a small bag of beans and we are devastated economically as beans are taking away our crops, wheat and maize, because we have to sell our wheat and maize to buy beans. Beans are robbing and exhausting our maize and our wheat."

\section{Marital challenges}

As indicated above beans are an important accompaniment for the staple dish injera in Ethiopia. The women's focus group discussion revealed that when the usual full meal, injera with shuro (bean or pea sauce) could not be offered by the wives, due to lack of beans or peas, 
the unsatisfied husbands were using "the lack of shuro" as an excuse to instigate conflicts with their wives. The husbands confessed to this in the mixed focus group discussion and also admitted that their wives did not have beans or peas at hand, or the financial resources to supply the dish of their desires. "We fail to see that it is not the women's own making." They expressed this thinking as "our own foolishness" and "lack of understanding".

\section{Discussion}

The results of the present study disclosed a negatively spiralling process in the highlands of Ethiopia, leading to impoverishment and reduced health, seriously counteracting the millennium development goal of eradicating poverty and hunger. The factors involved in this downward spiral include population development, the change from pastoralism to settled farming, diminishing land availability, a change from traditional crops to maize, food insecurity, crop theft and soil fertility management, all linked together in a chain of events difficult to curb.

With an increasing population the traditional life as pastoralists eventually had to give way to a development into settled farming. The land reform policy enacted in 1975 promoted "village formation" and land settlement (Ofcansky and Berry 1991). Land settlement included moving rural inhabitants from drought prone areas to fertile areas, such as Beseko, and it also entailed distributing land to landless peasants. With time, however, as the population continued to increase, the size of landholdings decreased (Pankhurst 2001) and many households ultimately found themselves in "landless" positions, a situation becoming prevalent in Sub-Saharan Africa (Ellis 2002).

In spite of being a centre of genetic diversity, Ethiopia has developed into one of the leading producers of maize in Sub-Saharan Africa (Byerlee and Eicher 1997), this at the cost of the traditional and important crops, like teff, barley and sorghum. The provisions of inputs, and policies conducive for specific crops like maize, brought this change about (McCann, 2001). This ultimately led to an impossible situation with a shortage of high yielding seed and the required fertilizer not being timely available as well as increasing in price.

During the discussions, farmers lamented that they felt "taken over" by maize. Their situation was further exacerbated by the vastly increased theft of beans, leading to an imminent change of their dietary habits and a decision to stop growing beans to avoid serious communal conflicts. This poses further challenges for the food security of these households, but it also resulted in a change of their inter-cropping patterns. Beans are nitrogen-fixing plants and consequently, not using beans in the crop rotation system had a negative impact on soil fertility in Beseko. In fact, amongst grain legumes, the faba bean, the bean type grown in the study area, is one of the best nitrogen-fixers and has an important role in the maintenance of soil fertility in 


\section{Crop Theft and Soil Fertility Management in the Highlands of Ethiopia - Chiwona-Karltun, Lemenih, Tolera, Berissso, and Karltun}

the wheat and barley cropping systems in the highlands of Ethiopia (Hailu et al. 1989; Amanuel et al. 2000). A study by Amanuel et al. (2000) in Ethiopia showed that the total amount of nitrogen fixed by faba beans ranges between $139-210 \mathrm{~kg} \mathrm{~N} \mathrm{ha}^{-1}$, across different sites.

Beans are the most important source of protein in the entire countryside of Ethiopia, and play a major role in the nutritional well-being of the population (Desta 1988). In the traditional perspective, there is an acceptance of children picking beans and this is not considered to be theft. In Beseku, however, bean picking increased to such an extent that it was regarded as theft. The phenomenon is very similar to the stealing of "sweet cassava", acceptable in small amounts, but beyond a certain level creating a crisis in terms of managing household food security (Chiwona-Karltun et al. 1998). That level of crop theft not only impedes food security and development, it creates serious conflicts in the community. In the present study we observed the effects of bean theft on three different levels:

1. Societal/community level - leading to conflict, mistrust and a breakdown in some of the kinship and ethnic relations.

2. Household level - husbands and wives in conflict over the ability of the wife to provide a good meal for the husband.

3. The individual/health status - a perceived deterioration of the health status, due to poor nutrition.

What is striking here is how the theft of a crop like beans causes major shifts not only in cropping patterns but also in human security and food and nutrition security. Dietary diversity is an important indicator of nutrition security. The farmers in this study had moved from a diverse cropping pattern to one dominated by maize cultivation and were also plagued with crop theft. The combination reaches beyond the normal issues of seasonality, hungry seasons and food shortage. What happens when societies are so weak socioeconomically - and when life is all about surviving from hand to mouth?

It has been argued that bean picking is a method of smoothing consumption patterns during periods of hunger and thirst for those in need, but not for those affected. As described by the Ethiopian proverb "you cannot pass a field of beans ripe for eating, it would be like passing beautiful girls without looking". The dilemma arises when "reasonable tasting" reaches the level of harvesting, which may be regarded as crop theft. Studies conducted by Blutton Jones (1987) and Bird and Bird (1997) on tolerated theft, i.e. food sharing, found that successful foragers 
shared their catch of the day with unsuccessful foragers based on their consumption, thereby creating a diminishing marginal return curve. However, this made sense only if the cost of not sharing was higher than the cost of sharing with others.

The problem in Beseko had reached such proportions that most farmers had stopped growing beans. Thieves were protected people, defended by his/her whole kin/clan, which often led to a large-scale risk of human insecurity. Youth were singled out as the main perpetrators, although mostly because of the hard socio-economic conditions. Faf Champs' and Mintens (2003) studies in Madagascar revealed that poverty is a major driver of theft; especially in remote rural areas people use theft as a risk coping and consumption smoothing strategy. Our findings in Beseko confirm these observations.

With the shortage of beans in the fields and households, beans have been fetching a high price on the market. Subsequently, the rural poor cannot afford this important basic nutritious ingredient in their sauce making. While some take matters into their own hands and steal, others suffer the consequences, and household discord and poor health ensue. As farmers and households have to sell more crops to afford the much-coveted beans, one can expect a deepening in impoverishment.

\section{Conclusion}

Farmers are globally, and those in Ethiopia in particular, facing a number of challenges on top of the obvious physical and economic constraints to manage soil fertility. Notwithstanding, the impact of climate, seasonality and deepening poverty on the livelihoods of these farming households is something that requires understanding in order to formulate the proper policies for rural development in Ethiopia. This study reflected on how thievery, especially theft of legume crops like beans, is affecting not only soil fertility but also other socio-economic aspects. Despite the focus of the paper being on bean theft, thievery in general is a major challenge in isolated rural areas. Crop theft requires us to extend our thinking beyond climate and seasonality, as it is largely related to food insecurity, both the transitory type and the chronic variant. Local interventions with the local indigenous institutions may help addressing the problem of crop theft being such a major impediment to soil fertility management as well as food security. 


\section{References}

Amanuel, G. Kühne, Tanner, D.G. and Vlek, P. L.G. (2000). Biological nitrogen fixation in faba bean (Vicia faba L.) in the Ethiopian highlands as affected by P fertilization and inoculation. Biology and Fertility of Soils, 3, 355-359, https://doi.org/10.1007/s003740000258

Black, R. and Watson, E.E. (2006). Local community, legitimacy, and cultural authenticity in post-conflict natural resource management: Ethiopia and Mozambique. Environment and Planning D: Society and Space, 24(2), 263 - 282, https://doi.org/10.1068/d0703

Bliege Bird, R and Bird, W. (1997). Delayed reciprocity and tolerated theft: The behavioural ecology of food sharing strategies. Current Anthropology, 38 (1), 49-78, https://doi.org/10.1086/204581

Blurton Jones, N.G. (1987). Tolerated theft, suggestions about the ecology and evolution of sharing, hoarding and scrounging. Biology and Social Life, 26 (1), 31-54, https://doi.org/10.1177/053901887026001002

Byerlee, D., and Eicher, C.K. (1997). Accelerating maize production: Synthesis. In D. Byerlee and C.K. Eicher (Eds.), Africa's Emerging Maize Revolution (pp. 249-250). Boulder, Colorado: Lynne Rienner Publishers.

Chiwona-Karltun, L., Mkumbira, J., Saka, J., Bovin, M., Mahungu, N.M. and Rosling, H. (1998). The importance of being bitter - a qualitative study on cassava cultivar preference in Malawi. Ecology of Food and Nutrition, 37(3), 219-245, https://doi.org/10.1080/03670244.1998.9991546

Chiwona-Karltun, L., Kambewa, P., Yajima, M., Mahungu, N.M. and Jiggins, J. (2005). Marketoriented responses among cassava farmers in Domasi, Malawi. Paper presented at HIV/AIDS and Food and Nutrition Security: from evidence to action. IFPRI International Conference, Durban - South Africa 14-16 April, 2005 [accessed July 16, 2007 at: http://www.ifpri.org/events/conferences/2005/durban/papers/chiwonakarltunWP.pdf.

Chowdhury A., Huffman S.L., and Chen L.C. (1981). Agriculture and nutrition in Matlab Thana, Bangladesh. In: Chambers R, Longhurst R and Pacey A (Eds.). Seasonal dimensions to rural poverty (pp. 52-66). Frances Printer Publishers. 
Clay E.J. (1981). Seasonal patterns of agricultural employment in Bangladesh. In R. Chambers, R. Longhurst, and A. Pacey (Eds.) Seasonal dimensions to rural poverty (pp. 92-101). London: Frances Printer Publishers 92-101.

Collier, P. (2007). The bottom billion: why the poorest countries are failing and what can be done about it. London: Oxford University Press.

de Boef, W., K. Amanor, K., and Wellard, K. (Eds). (1993). Cultivating knowledge, genetic diversity, farmer experimentation and crop research. London: Intermediate Technology Publications Ltd., https://doi.org/10.3362/9781780441924

Desta B. (1988). Biological nitrogen fixation research on grain legumes in Ethiopia: an overview. In D.P. Beck and L.A. Materon (Eds.) Nitrogen fixation by legumes in Mediterranean agriculture (pp. 73-78). Nijhoff: Dordrecht.

Devereux, s. and Guenther, B., 2007. Social protection and agriculture in Ethiopia. Institution of development studies, University of Sussex. Available at: www.fao.org/es/esa/pdf/workshop_0108_ethiopia.pdf [accessed 7 April 2013].

Devereux, S., 2000. Food insecurity in Ethiopia. [On line]. Available at: http://cramforum.jrc.it/Shared\%20Documents/Food\%20Insecurity\%20in\%20Ethiopia.pdf [accessed 19 February 2013.]

Elias E. and Scoones I. (1999). Perspectives on soil fertility change: a case study from southern. Ethiopia. Land Degradation and Development, 10, 195-206, https://doi.org/10.1002/(SICI)1099-145X(199905/06)10:3<195::AIDLDR328>3.0.CO;2-N

Ellis, F. (2000). Rural livelihoods and diversity in developing countries. London: Oxford University Press.

Ensminger J (1990). Co-Opting the Elders: The Political Economy of State Incorporation in Africa. American Anthropologist, 92(3), 662-675, https://doi.org/10.1525/aa.1990.92.3.02a00070

Fafchamps, M. and Minten, B. (2003). Theft and rural poverty: Result of a natural experiment. Proceedings of the 25th International Conference of Agricultural Economics (IAAE). Dubin: South Africa, https://doi.org/10.4337/9781781950685 
Fafchamps, M. (2006). Development and social capital. Journal of Development Studies, 42(7), 1180-1198, https://doi.org/10.1080/00220380600884126

Hailu G., Amsal T., and Endale A. (1989). Beneficial break crops for wheat production. Ethiopian Journal of Agricultural Science, 11, 15-24.

Karltun, E. et al., 2008. Working with farmers and local institutions to improve soil quality in sub-Saharan Africa.Currents, 43, 7-11. Available at: http/www.info.slu.se/currents/2008/currents43 [accessed 12 October 2008].

Legesse, A (1973). Gada: Three approaches to the study of African society. London: Macmillan.

Lemenih, M. (2004). Effect of land use changes on soil quality: native flora degradation and restoration in the highland of Ethiopia. Implications for sustainable land management. Doctoral Thesis. Uppsala, Swedish University of Agricultural Sciences.

Lemenih,M., Karltun,E., and Olsson,M. (2005). Soil organic matter dynamics after deforestation along a farm field chronosequence in southern highlands of Ethiopia. Agriculture Ecosystems and Environment, 109, 9-19, https://doi.org/10.1016/j.agee.2005.02.015

Mkumbira J (2002). Cassava development for small-scale farmers: approaches to breeding in Malawi. Doctoral Thesis. Uppsala: The Swedish University of Agricultural Sciences.

Ofcansky, T., and Berry, L. (1991). Ethiopia: a country study. Washington, US library of congress. [On line] Available at:- http://countrystudies.us/ethiopia/45.htm. [accessed 15 March 2009]

Pankhurst, A. (2001). Conflict management over contested natural resources: a case study of pasture, forest and irrigation in South Wello, Ethiopia. Rome: Food and Agriculture Organization of the United Nations.

Reij, C., Scoones, I., and Toulmin, C. (Eds.). (1996). Sustaining the soil: indigenous soil and water conservation in Africa. London: Earthscan Publications

Rubin, H., and Rubin, I (2005). Qualitative interviewing: the art of hearing data. London: SAGE publication. 
International Journal of Rural Criminology, Volume 3, Issue 2 (June), 2017

Sachs, J.D. and Warner, Andrew M. (2001). The curse of natural resources. European Economic Review, 45(4-6), 827-838, https://doi.org/10.1016/S0014-2921(01)00125-8

Teklu, T. (2004). Natural resource scarcity and rural conflict: case studies evidence on correlates from Ethiopia. [On line]. Available at: www.eeaecon.org/EEA/conferences/papers/Tesfaye \%20Teklu\%20\%20ENVIRONMENT-CONFLICTS-ETHIOPIA-JUNEPAPER [Accessed 10 December 2008].

van de Pol, F. (1992). Soil mining: An unseen contributor to farm income in southern Mali. Bulletin. 325. Amsterdam: Royal Tropical Institute.

Watson, E. E. (2003). Examining the potential of indigenous institutions for development: the case from Borana, Ethiopia. Development and Change, 35, 287-309, https://doi.org/10.1111/1467-7660.00306 